\title{
Expression of Ion Channels in Perivascular Stem Cells derived from Human Umbilical Cords
}

\author{
Eunbi Kim ${ }^{1}$, Won Sun Park ${ }^{2}$ and ${ }^{\dagger}$ Seok-Ho Hong ${ }^{1}$ \\ ${ }^{1}$ Department of Internal Medicine, School of Medicine, Kangwon National University, Chuncheon 24341, Korea \\ ${ }^{2}$ Department of Physiology, School of Medicine, Kangwon National University, Chuncheon 24341, Korea
}

\begin{abstract}
Potassium channels, the largest group of pore proteins, selectively regulate the flow of potassium $\left(\mathrm{K}^{+}\right)$ions across cell membranes. The activity and expression of $\mathrm{K}^{+}$channels are critical for the maintenance of normal functions in vessels and neurons, and for the regulation of cell differentiation and maturation. However, their role and expression in stem cells have been poorly understood. In this study, we isolated perivascular stem cells (PVCs) from human umbilical cords and investigated the expression patterns of big-conductance $\mathrm{Ca}^{2+}$-activated $\mathrm{K}^{+}\left(\mathrm{BK}_{\mathrm{Ca}}\right)$ and voltage-dependent $\mathrm{K}^{+}\left(\mathrm{K}_{\mathrm{v}}\right)$ channels using the reverse transcription polymerase chain reaction. We also examined the effect of high glucose ( $\mathrm{HG}, 25 \mathrm{mM})$ on expression levels of $\mathrm{BK}_{\mathrm{Ca}}$ and $\mathrm{K}_{\mathrm{v}}$ channels in PVCs. $\mathrm{K}_{\mathrm{Ca}} 1.1, \mathrm{~K}_{\mathrm{Ca}} \beta_{3}, \mathrm{~K}_{\mathrm{v}} 1.3, \mathrm{~K}_{\mathrm{v}} 3.2$, and $\mathrm{K}_{\mathrm{v}} 6.1$ were detected in undifferentiated PVCs. In addition, $\mathrm{HG}$ treatment increased the amounts of $\mathrm{BK}_{\mathrm{Ca}} \beta_{3 \mathrm{a}}, \mathrm{BK}_{\mathrm{Ca}} \beta_{4}, \mathrm{~K}_{\mathrm{v}} 1.3, \mathrm{~K}_{\mathrm{v}} 1.6$, and $\mathrm{K}_{\mathrm{v}} 6.1$ transcripts. These results suggested that ion channels may have important functions in the growth and differentiation of PVCs, which could be influenced by HG exposure.
\end{abstract}

Key words : Perivascular stem cell, Ion channel, High glucose, Cell therapy

\section{INTRODUCTION}

Perivascular stem cells (PVCs), originating from mesenchymal stem cells (MSCs), have greater proliferation and differentiation potentials compared to those of bone marrow-derived MSCs (Crisan et al., 2008). Among the PVC sources, human umbilical cords (HUC) have some advantages over other tissues because they are easily accessible as a clinical waste product and have low inherent immunogenicity (Nagamura-Inoue et al., 2014). For these reasons, HUCPVCs have drawn considerable interest as a promising material for regenerative medicine. In recent years, the therapeutic effects of HUCPVCs on various di- seases have been reported. Tsang et al. (2013) showed that HUCPVCs contributed to skeletal regeneration by generating a matrix and recruiting resident progenitors in a bone defect model. HUCPVCs also contributed to the repair of injured lung tissue as well as protected against neurodegenerative diseases through paracrine effects (Montemurro et al., 2011; Appaix et al., 2014). Thus, the identification and functional assessment of internal and external factors regulating PVC functions are critical for improving their therapeutic potential.

Potassium channels, the largest group of pore proteins, are widely distributed in various cell types (Day et al., 1993; Park et al., 2007). They selectively regulate the flow

\footnotetext{
Manuscript received December 25, 2016, Received in revised form December 29, 2016, Accepted January 5, 2017

${ }^{\dagger}$ Corresponding Author : Dr. Seok-Ho Hong, Department of Internal Medicine, School of Medicine, Kangwon National University, Kangwondaehakgil-1, Chuncheon, Gangwon-do 24341 Republic of Korea. Tel: +82-33-250-7819, Fax: +82-33-244-2367, Email: shhong@kangwon.ac.kr

This is an Open Access article distributed under the terms of the Creative Commons Attribution Non-Commercial License (http:// creativecommons.org/licenses/by-nc/3.0) which permits unrestricted non-commercial use, distribution, and reproduction in any medium, provided the original work is properly cited.
} 
of potassium $\left(\mathrm{K}^{+}\right)$ions across cell membranes (Day et al., 1993). $\mathrm{K}^{+}$channels have important roles in maintaining normal functions and physiological homeostasis in various cell types as well as regulating the cell cycle, differentiation, and maturation (Kawano et al., 2002). Although several studies have characterized the electrophysiological properties of MSCs and pluripotent stem cells (Heubach et al., 2003; Li et al., 2005; Wang et al. 2005; Bai et al., 2007; Park et al., 2007; Jiang et al., 2010; Park et al., 2013; Tarasov et al., 2017), the expression and function of ion channels in HUCPVCs have not been studied. Therefore, for therapeutic applications, we need to investigate not only the multi-lineage differentiation capacity, but also the electrophysiological properties of $\mathrm{K}^{+}$channels in HUCPVCs. In the present study, we investigated the expression patterns of big-conductance $\mathrm{Ca}^{2+}$-activated $\left(\mathrm{BK}_{\mathrm{Ca}}\right)$ and voltage-dependent $\mathrm{K}^{+}\left(\mathrm{K}_{\mathrm{v}}\right)$ channels in undifferentiated HUCPVCs and examined the effects of high glucose (HG, 25 $\mathrm{mM}$ ) on the expression levels of $\mathrm{BK}_{\mathrm{Ca}}$ and $\mathrm{K}_{\mathrm{v}}$ channels.

\section{MATERIALS AND METHODS}

\section{Cell isolation and culture}

HUC tissues $(n=3)$ were obtained from mothers undergoing Caesarian sections, with written informed consent after approval by the Institutional Review Board of Kangwon National University Hospital. The isolation and culturing of HUCPVCs were performed as described previously (An et al., 2015a). Briefly, HUCs were rinsed with sterile phosphate-buffered saline (PBS; Sigma-Aldrich) and incised along their length in dishes. Both ends of the isolated vessels were ligated with black silk and then transferred into $100 \mathrm{~mm}$ culture dishes containing $\alpha$-minimal essential media (MEM) supplemented with 10\% fetal bovine serum (FBS; Hyclone), 1\% penicillin-streptomycin (Sigma-Aldrich) and amphotericin B $(0.3 \mu \mathrm{g} / \mathrm{mL}$; SigmaAldrich). After 7-10 days, the vessels were removed from the dishes and the colonies were subcultured. Once the cells reached $80 \%$ confluency, they were passaged by treatment with $0.05 \%$ trypsin-EDTA (Sigma-Aldrich). To evaluate the effect of high glucose on the expression of ion channels in PVCs, the cells were plated at a density of $4 \times 10^{5}$ cells in $35 \mathrm{~mm}$ dishes and cultured in $\alpha$-MEM medium supplemented with low glucose (LG) $(1.0 \mathrm{~g} / \mathrm{L}, 5 \mathrm{mM})$ and $\mathrm{HG}(4.5 \mathrm{~g} / \mathrm{L}, 25 \mathrm{mM})$ for 5 days.

\section{Flow cytometry analysis}

HUCPVCs were dissociated into single cells using trypsin-EDTA and resuspended in $1 \%$ FBS-PBS. The cells were filtered through a $70 \mu \mathrm{m}$ cell strainer and reacted with the following antibodies conjugated with fluorochrome for $1 \mathrm{hr}$ at $4{ }^{\circ} \mathrm{C}$ : CD31-phycoerythrin (PE), CD34fluorescein-isothiocyanate (FITC), CD45-allophycoerythrin (APC), CD44-APC, CD90-APC, CD146-FITC, and SSEA-4-FITC (all, BD Biosciences). The dead cells were excluded with 7-aminoactinomycin D. Stained cells were analyzed using the FACSCanto II (BD Biosciences) and data were analyzed by FlowJo software (FlowJo).

\section{Reverse transcription polymerase chain reaction} (RT-PCR) and quantitative real-time PCR analysis

Total RNA was isolated using the RNeasy Mini Kit (Qiagen) according to the manufacturer's instructions. Briefly, total RNA was reverse transcribed by using the TOPscript $^{\mathrm{TM}}$ RT DryMIX kit (\#RT200; Enzynomics). Transcripts were quantitated using TOPreal ${ }^{\mathrm{TM}}$ qPCR $2 \mathrm{X}$ PreMIX (\#RT501S; Enzynomics) and the ABI StepOnePlus ${ }^{\mathrm{TM}}$ System Instrument (Applied Biosystems). The expression levels of $\mathrm{BK}_{\mathrm{Ca}}$ and $\mathrm{K}_{\mathrm{v}}$ channel genes were normalized to glyceraldehyde 3-phosphate dehydrogenase (GAPDH) and the relative quantification was performed using the comparative CT method according to the manufacturer's instructions (Applied Biosystems). The primer sequences are listed in Table 1. 
Table 1. List of primer sequences for RT-PCR

\begin{tabular}{|c|c|c|}
\hline Gene & Forward ( $5^{\prime}$ to $\left.3^{\prime}\right)$ & Reverse (5' to $\left.3^{\prime}\right)$ \\
\hline $\mathrm{BK}_{\mathrm{Ca}} 1.1$ & AGGAATGCATCTTGGCGTCACT & GCGGCAGCGGTCCCTATT \\
\hline $\mathrm{BK}_{\mathrm{Ca}} 2.1$ & TGGAGGGGGCAGCTGAAGGAGAAC & CCGCCCCACGCTGCCATTGT \\
\hline $\mathrm{BK}_{\mathrm{Ca}} 2.2$ & CCACCAATTCCGGACGCAGTA & GGGACCGCTCAGCATTGTAAGTG \\
\hline $\mathrm{BK}_{\mathrm{Ca}} 2.3$ & AGCCACCGCATCCCCTGTCTCA & TGCCGGCATGCTGGTGGTTG \\
\hline $\mathrm{BK}_{\mathrm{Ca}} 3.1$ & CACCCTAGCCCCTCCTTATTCTCA & CCGGGGTCTTGGGGCTCAG \\
\hline $\mathrm{BK}_{\mathrm{Ca}} 4.1$ & AGACGCCAAGGCCTACGGGTTCAA & CTCGGCGCTCATGGTGCTCTCCTT \\
\hline $\mathrm{BK}_{\mathrm{Ca}} \beta_{1}$ & GGCGGCCCAGAAGTAGAGC & ATGCAGCCGGAAACAGGTATGAGT \\
\hline $\mathrm{BK}_{\mathrm{Ca}} \beta_{2}$ & CAAAGCGGCGAGTGGTGT & TCCCCGGAAGAAGTCAGGTTA \\
\hline $\mathrm{BK}_{\mathrm{Ca}} \beta_{3 \mathrm{a}}$ & CGAGGCGGAAACACAGG & GGCAAGGCGGAGCGGTCAGT \\
\hline $\mathrm{BK}_{\mathrm{Ca}} \beta_{4}$ & CAGCGGGCGATGGAGACAGAGA & ACGACGCCGGAGATGATGAGAAAC \\
\hline $\mathrm{K}_{\mathrm{V}} 1.1$ & CATCTGGTTCTCCTTCGAGC & GTTAGGGGAACTGACGTGGA \\
\hline $\mathrm{K}_{\mathrm{V}} 1.2$ & TCCGGGATGAGAATGAAGAC & TTGGACAGCTTGTCACTTGC \\
\hline $\mathrm{K}_{\mathrm{v}} 1.3$ & GTTCTCCTTCGAACTGCTGG & CTGAAGAGGAGAGGTGCTGG \\
\hline $\mathrm{K}_{\mathrm{v}} 1.4$ & CCCCAGCTTTGATGCCATCTTG & TGAGGATGGCAAAGGACATGGC \\
\hline $\mathrm{K}_{\mathrm{v}} 1.5$ & TGCGTCATCTGGTTCACCTTCG & TGTTCAGCAAGCCTCCCATTCC \\
\hline $\mathrm{K}_{\mathrm{v}} 1.6$ & TCAACAGGATGGAAACCAGCCC & CTGCCATCTGCAACACGATTCC \\
\hline $\mathrm{K}_{\mathrm{v}} 1.7$ & TGCCCTTCAATGACCCGTTCTTC & AAGACACGCACCAATCGGATGAC \\
\hline $\mathrm{K}_{\mathrm{v}} 2.1$ & TACAGCCTCGACGACAACG & ACCACGCGGCGGACATTCTG \\
\hline $\mathrm{K}_{\mathrm{v}} 2.2$ & AACGAACTGAGGCGAGAG & ACTCCGCCTAAGGGTGAAAC \\
\hline $\mathrm{K}_{\mathrm{v}} 3.1$ & AACCCCATCGTGAACAAGACGG & TCATGGTGACCACGGCCCA \\
\hline $\mathrm{K}_{\mathrm{v}} 3.2$ & CTGCTGCTGGATGACCTACC & TGTGCCATTGATGACTGGTT \\
\hline $\mathrm{K}_{\mathrm{v}} 3.3$ & TTCTGCCTGGAAACCCATGAGG & TGTTGACAATGACGGGCACAGG \\
\hline $\mathrm{K}_{\mathrm{v}} 4.1$ & ATCTCGAGGAGATGAGGTTC & TTCTTTCGGTCCCGATAC \\
\hline $\mathrm{K}_{\mathrm{v}} 4.3$ & TGGCTTCTTCATCGCTGTCTCG & CCGAAGATCTTCCCTGCAATCG \\
\hline $\mathrm{K}_{\mathrm{v}} 4.4$ & AGCCAAGAAGAACAAGCTG & AGGAAGTTTAGGACATGCC \\
\hline $\mathrm{K}_{\mathrm{v}} 5.1$ & TCCACATGAAGAAGGGCATCTGC & TCACGTAGAAGGGGAGGATG \\
\hline $\mathrm{K}_{\mathrm{v}} 6.1$ & TGCACCAACTTCGACGACATCC & GGAACTCCAGGGAGAACCAGCC \\
\hline $\mathrm{K}_{\mathrm{v}} 6.2$ & AAGCTCTTCGCCTGCGTGTC & CAGCAGCAGCGACACGTAGAAC \\
\hline $\mathrm{K}_{\mathrm{v}} 6.3$ & ATGCCCATGCCTTCCAGAGA & AGAGCTGCACGATCTCCTCG \\
\hline $\mathrm{K}_{\mathrm{v}} 8.1$ & TTCCACAGCTGCCCGTATCTTTG & TTTTGCCTGTGGTGGTGTCTGG \\
\hline $\mathrm{K}_{\mathrm{v}} 9.1$ & TTTGAGGACTTGCTGAGCAGCG & TTGCTCCAGGCACACCAACAAG \\
\hline $\mathrm{K}_{\mathrm{v}} 9.2$ & GTACTGGGGCATCAACGAGT & CCACGGAGAGGTAGAGCAAG \\
\hline $\mathrm{K}_{\mathrm{v}} 9.3$ & CTCTGTGGGCATTTCCATTT & AGAAACAGGCACAAACACCC \\
\hline $\mathrm{K}_{\mathrm{v}} 10.1$ & GCTTGCCCGTCACTTCATTGGTC & TTCTTCCAGGCACTGTGATAGGA \\
\hline $\mathrm{K}_{\mathrm{V}} 11.1$ & AGCCATGCTCAAACAGAGTG & CTCCTCGTAGTCGTCGCACA \\
\hline GAPDH & TGCACCACCAACTGCTTAGC & GGCATGGACTGTGGTCATGAG \\
\hline
\end{tabular}

\section{Data analysis}

All results were expressed as mean \pm standard error of mean (SEM). Student's $t$-test was used to determine statistical significance. We considered $* p<0.05$ to be statistical- ly significant.

\section{RESULTS}

1. Characterization of HUCPVCs 
We obtained PVCs from the vessels of HUC tissues using a non-enzymatic (NE) isolation method (An et al., 2015b). To prevent cross contamination with hematopoietic and endothelial cells, both ends of the vessel were ligated and then plated into dishes. On days 7-10 postplating, PVC colonies were subcutured and successfully expanded. HUCPVCs exhibited fibroblast or spindle-like morphology (Fig. 1A). The phenotypic expression of HUCPVCs (Passage 2) was analyzed by flow cytometry. The cells were positive for CD146 (93\%), SSEA-4 (10.1 \%), CD44 (99.9\%), and CD90 (99\%), and negative for CD31, CD45, and CD34, which precluded contamination by endothelial and hematopoietic cells (Fig. 1B). These results suggested that the NE method enabled us to obtain a homogenous PVC population and that the expression pattern of surface markers on HUCPVCs was in agreement with that of human PVCs reported in previous studies.

2. High glucose treatment alters the expression of $\mathrm{BK}_{\mathrm{Ca}}$ and $\mathrm{Kv}$ channels in undifferentiated HUCPVCs

We first investigated the expression patterns of $\mathrm{BK}_{\mathrm{Ca}}$ and $K_{\mathrm{V}}$ channel subtypes in undifferentiated HUCPVCs. We found comparable mRNA expression of $\mathrm{K}_{\mathrm{Ca}} \beta_{3 \mathrm{a}}$ and $\mathrm{K}_{\mathrm{V}} 1.3$ subtypes in undifferentiated HUCPVCs (Fig. 2A and 2B). The expression levels of $\mathrm{BK}_{\mathrm{Ca}} 1.1, \mathrm{BK}_{\mathrm{Ca}} 2.2, \mathrm{~K}_{\mathrm{Ca}} \beta$, $\mathrm{K}_{\mathrm{v}} 3.3$, and $\mathrm{K}_{\mathrm{v}} 6.1$ subtypes were relatively low (Fig. 2A

A
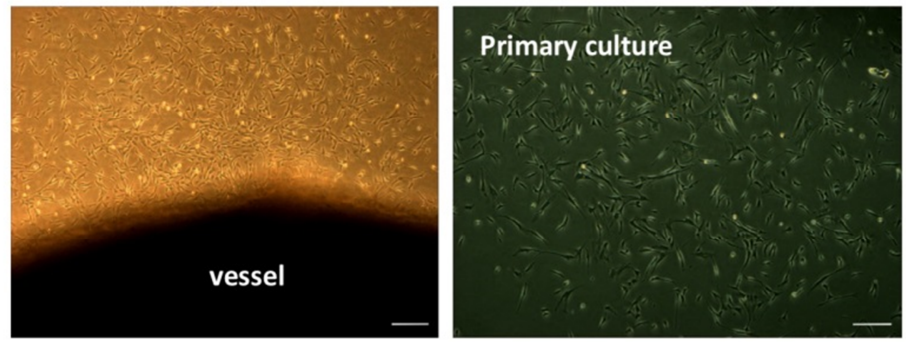

Passsage 1

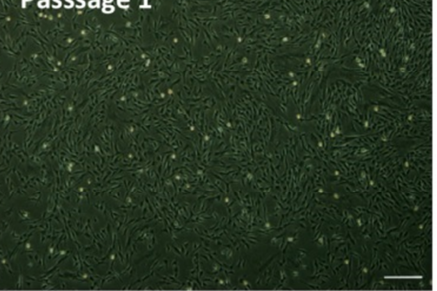

B

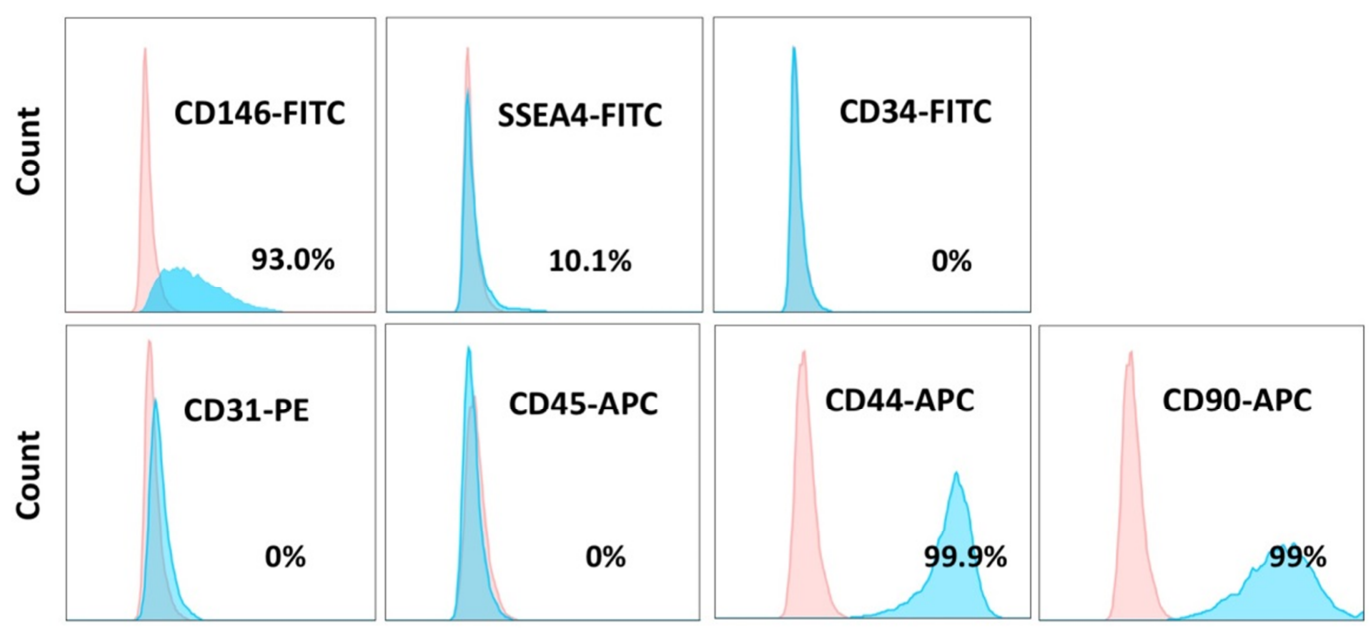

Fig. 1. Isolation and characterization of HUCPVCs. (A) Non-enzymatic isolation of HUCPVCs. Both ends of the dissected vessel were ligated and plated into a $100 \mathrm{~mm}$ dish. Perivascular stem cell (PVC) colonies were collected and subcultured when $80 \%$ confluent. Scale bar, $100 \mu \mathrm{m}$. (B) Phenotypes of isolated HUCPVCs were analyzed by flow cytometry. PVC marker, CD146; MSC markers, CD44 and CD90; endothelial and hematopoietic markers, CD31, CD34, and CD45. HUCPVC = human umbilical cords perivascular stem cells; MSC = mesenchymal stem cells. 

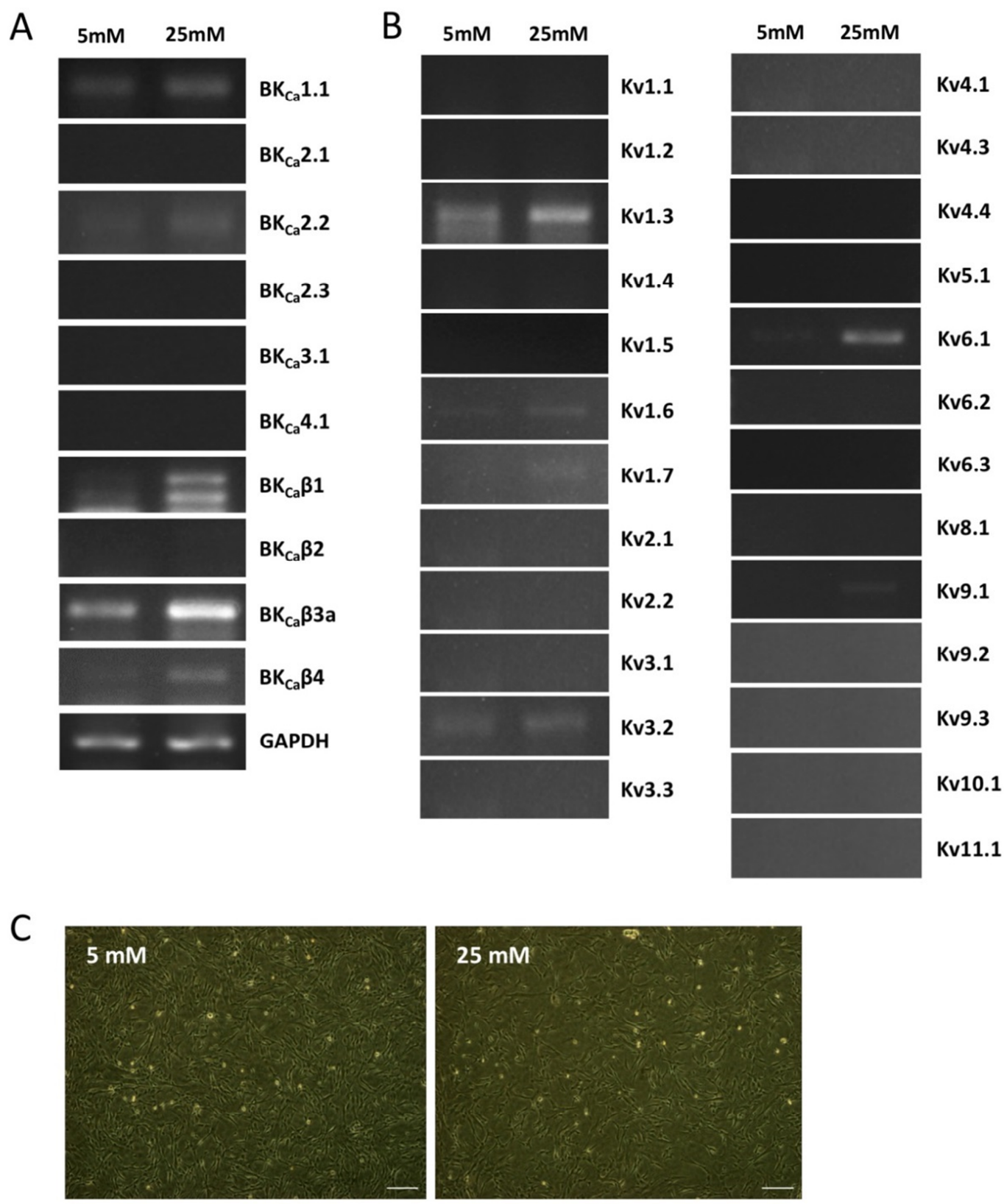

Fig. 2. Expression of $B K_{C a}$ and $K_{v}$ channel subtypes in HUCPVCs treated with LG and HG. (A) The mRNA expression of $\mathrm{BK}_{\mathrm{Ca}}$ channel subtypes in HUCPVCs cultured with LG and HG by RT-PCR. The expression levels of $\mathrm{BK}_{\mathrm{Ca}} \beta_{3 \mathrm{a}}$ and $\mathrm{BK}_{\mathrm{Ca}} \beta_{4}$ subtypes were increased in HG-treated HUCPVCs. (B) The mRNA expression of $\mathrm{K}_{\mathrm{v}}$ channel subtypes in HUCPVCs cultured with LG and HG measured by RT-PCR. The expression levels of $\mathrm{K}_{\mathrm{v}} 1.3, \mathrm{~K}_{\mathrm{v}} 1.6$, and $\mathrm{K}_{\mathrm{v}} 6.1$ subtypes were increased in HG-treated HUCPVCs. (C) Representative images of HUCPVCs cultured in LG ( $5 \mathrm{mM})$ and HG (25 mM) conditions for 5 days. Scale bar, $100 \mu \mathrm{m}$. LG = low glucose; HG = high glucose. Other abbreviations are as in Fig. 1.

and 2B). High concentrations of glucose in the blood affected the growth and functions of endogenous stem cells. Thus, we next asked if high glucose influenced the expres- sion levels of ion channels. HUCPVCs were plated at a density of $4 \times 10^{5}$ cells in $35 \mathrm{~mm}$ dishes and cultured in both LG and HG conditions for 5 days. HG did not induce 

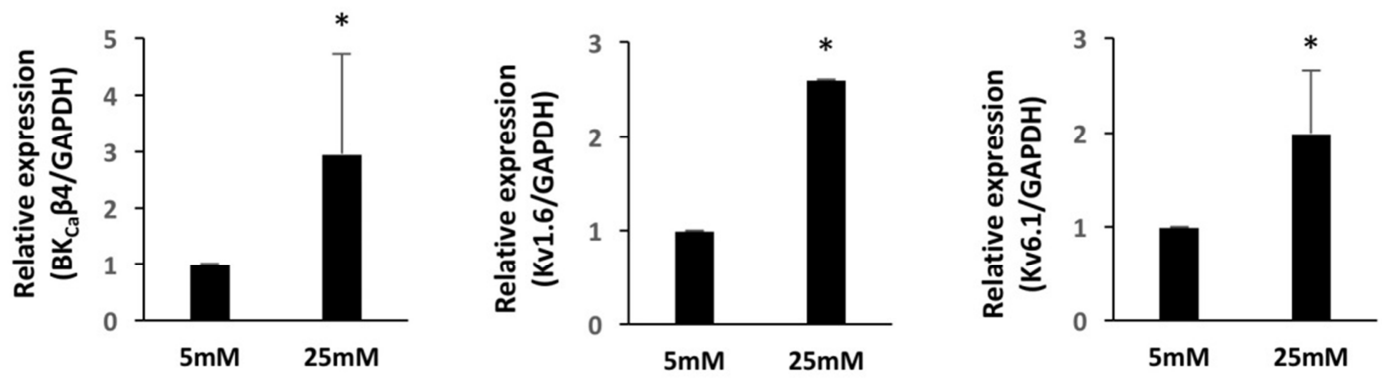

Fig. 3. Upregulation of $B K_{C a} \beta_{4}, K_{v} 1.6$ and $K_{v} 6.1$ subtypes in HG-treated HUCPVCs. Real-time qPCR was used for confirmation of upregulated subtypes in HG-treated HUCPVCs. Error bars indicate SEM. * $p<0.05$. Other abbreviations are as in Fig. 1.

morphological changes in HUCPVCs (Fig. 2C), but reduced the proliferative activity (data not shown). HGtreated HUCPVCs showed increased mRNA levels of $\mathrm{BK}_{\mathrm{Ca}} \beta_{3 \mathrm{a}}, \mathrm{BK}_{\mathrm{Ca}} \beta_{4}, \mathrm{~K}_{\mathrm{v}} 1.3, \mathrm{~K}_{\mathrm{v}} 1.6$, and $\mathrm{K}_{\mathrm{v}} 6.1$ subtypes. We confirmed the upregulation of $\mathrm{BK}_{\mathrm{Ca}} \beta_{4}, \mathrm{~K}_{\mathrm{v}} 1.6$, and $\mathrm{K}_{\mathrm{v}} 6.1$ transcripts in HUCPVCs exposed to HG using quantitative real-time PCR (Fig. 3). These results suggested that $\mathrm{BK}_{\mathrm{Ca}}$ and $\mathrm{K}_{\mathrm{v}}$ channels may have unique functions in the growth and differentiation of HUCPVCs, which could be affected by $\mathrm{HG}$ exposure.

\section{DISCUSSION}

In the present study, we showed for the first time the expression patterns of $\mathrm{BK}_{\mathrm{Ca}}$ and $\mathrm{K}_{\mathrm{v}}$ ion channels in HUCPVCs, which could be altered by exposure to HG. In recent years, PVCs have been suggested as a promising source for cell-based therapy due to their greater regenerative potential (Crisan et al., 2008). Ion channels are detected in a variety of cell types and play fundamental roles in controlling cell proliferation and differentiation as well as maintaining homeostasis (Kawano et al., 2002). Therefore, we investigated the electrophysiological properties of HUCPVCs to improve their proliferative and regenerative capacities.

Recent studies reported the electrophysiological properties of multipotent MSCs and found that the expression patterns of ion channels were relatively heterogeneous among MSCs. While similar expression levels of Kv1.4, Kv4.1, Kv4.2, and Kv4.3 subtypes were observed between adipose tissues (AD)- and bone marrow (BM)-derived MSCs, expression of Kv1.1, Kv1.4, and Kv7.3 subtypes varied across the tissues or among studies (Heubach et al., 2003; Li et al., 2005; Bai et al., 2007; Park et al., 2007; Park et al., 2013). Bai et al. (2007) could not detect Kv4.1 subtype in AD-MSCs. However, Park et al. (2013) reported strong expression of Kv4.1 subtype in AD-MSCs. The heterogeneity of $\mathrm{Kv}$ ion channels in MSCs may be attributed to variations among donors or the tissues from which MSCs are isolated. Our data showed different expression patterns of ion channel subtypes in PVCs compared with AD- and BM-MSCs, indicating that PVCs are different subpopulations and are more homogeneous than MSCs. Culture conditions might also influence the expression of specific ion channel subtypes detected in MSCs. For example, BM-MSCs cultured in HG medium exhibited senescence and genetic instability by upregulation of autophagy and oxidative stress (Chang et al., 2015). In addition, hyperglycemia impaired the proliferation and function of endogenous stem and somatic cells such as MSCs, hematopoietic stem cells and Müller cells (Kim et al., 2015; Kocabas et al., 2015; Manea et al., 2015; Hadarits et al., 2016; Qiu et al., 2016). Thus, we assumed that the glucose concentration in the culture medium may affect the expres- 
sion levels of ion channels in PVCs and found increased levels of $\mathrm{BK}_{\mathrm{Ca}} \beta_{3 \mathrm{a}}, \mathrm{BK}_{\mathrm{Ca}} \beta_{4}, \mathrm{~K}_{\mathrm{v}} 1.3, \mathrm{~K}_{\mathrm{v}} 1.6$, and $\mathrm{K}_{\mathrm{v}} 6.1$ transcripts in HG-treated PVCs compared to those of LGtreated PVCs.

In summary, this is the first characterization of ion channels in HUCPVCs, which provides fundamental information to improve the regenerative capacity of HUCPVCs. Further study will be needed to define the physiological roles of specific ion channels in the proliferation and differentiation of HUCPVCs.

\section{ACKNOWLEDGEMENTS}

This work was supported by a grant from the Ministry of Science, ICT and Future Planning (2016R1A2B4014890) and Kangwon National University (2015).

\section{REFERENCES}

An B, Na S, Lee S, Kim WJ, Yang SR, Woo HM, Kook S, Hong Y, Song H, Hong SH (2015a) Non-enzymatic isolation followed by supplementation of basic fibroblast growth factor improves proliferation, clonogenic capacity and SSEA-4 expression of perivascular cells from human umbilical cord. Cell Tissue Res 359:767777.

An B, Heo HR, Lee S, Park JA, Kim KS, Yang J, Hong SH (2015b) Supplementation of growth differentiation factor-5 increases proliferation and size of chondrogenic pellets of human umbilical cord-derived perivascular stem cells. Tissue Eng Regen Med 12:181-187.

Appaix F, Nissou MF, van der Sanden B, Dreyfus M, Berger F, Issartel JP, Wion D (2104) Brain mesenchymal stem cells: The other stem cells of the brain? World J Stem Cells 6:134-143.

Bai X, Ma J, Pan Z, Song YH, Freyberg S, Yan Y, Vykoukal D, Alt E (2007) Electrophysiological properties of human adipose tissue-derived stem cells. Am J Phy- siol Cell Physiol 293:C1539-C1550.

Chang TC, Hsu MF, Wu KK (2015) High glucose induces bone marrow-derived mesenchymal stem cell senescence by upregulating autophagy. PLos One 10: e0126537.

Crisan M, Yap S, Casteilla L, Chen CW, Corselli M, Park TS, Andriolo G, Sun B, Zheng B, Zhang L, Norotte C, Teng PN, Traas J, Schugar R, Deasy BM, Badylak S, Buhring HJ, Giacobino JP, Lazzari L, Huard J, Péault B (2008) A perivascular origin for mesenchymal stem cells in multiple human organs. Cell Stem Cell 3:301313.

Day ML, Pickering SJ, Johnson MH, Cook DI (1993) Cellcycle control of a large-conductance $\mathrm{K}$ channel in mouse early embryos. Nature 365:560-562.

Hadarits O, Zóka A, Barna G, Al-Aissa Z, Rosta K, Rigó J Jr, Kautzky-Willer A, Somogyi A, Firneisz G (2016) Increased proportion of hematopoietic stem and progenitor cell population in cord blood of neonates born to mothers with gestational diabetes mellitus. Stem Cells Dev 24:575-586.

Heubach JF, Graf EM, Leutheuser J, Bock M, Balana B, Zahanich I, Christ T, Boxberger S, Wettwer E, Ravens U (2004) Electrophysiological properties of human mesenchymal stem cells. J Physiol 554:659-672.

Jiang P, Rushing SN, Kong CW, Fu J, Lieu DK, Chan CW, Deng W, Li RA (2010). Electrophysiological properties of human induced pluripotent stem cells. Am J Physiol Cell Physiol 298:C486-C495.

Kawano S, Shoji S, Ichinose S amagata K, Tagami M, Hiraoka $\mathrm{M}$ (2002) Characterization of $\mathrm{Ca}_{2}$ signaling pathways in human mesenchymal stem cells. Cell Calcium 32:165-174.

Kim J, Piao Y, Pak YK, Chung D, Han YM, Hong JS, Jun EJ, Shim JY, Choi J, Kim CJ (2015) Umbilical cord mesenchymal stromal cells affected by gestational diabetes mellitus display premature aging and mitochondrial dysfunction. Stem Cells Dev 24:575-586.

Kocabas F, Xie L, Xie J, Yu Z, DeBerardinis RJ, Kimura W, Thet S, Elshamy AF, Abouellail H, Muralidhar S, 
Liu X, Chen C, Sadek HA, Zhang CC, Zheng J (2015) Hypoxic metabolism in human hematopoietic stem cells. Cell Biosci 5:39.

Li GR, Sun H, Deng X, Lau CP (2005) Characterization of ionic currents in human mesenchymal stem cells from bone marrow. Stem Cells 23:371-382.

Manea A, Manea SA, Todirita A, Albulescu IC, Raicu M, Sasson S, Simionescu M (2015) High-glucose-increased expression and activation of NADPH oxidase in human vascular smooth muscle cells is mediated by 4-hydroxynonenal-activated PPAR $\alpha$ and PPAR $\beta / \delta$. Cell Tissue Res 361:593-604.

Montemurro T, Andriolo G, Montelatici E, Weissmann G, Crisan M, Colnaghi MR, Rebulla P, Mosca F, Péault B, Lazzari L (2011) Differentiation and migration properties of human foetal umbilical cord perivascular cells: potential for lung repair. J Cell Mol Med 15: 796-808.

Nagamura-Inoue T, He H (2014) Umbilical cord-derived mesenchymal stem cells: Their advantages and potential clinical utility. World J Stem Cells 6:195-202.

Park KS, Jung KH, Kim SH, Kim KS, Choi MR, Kim Y, Chai YG (2007) Functional expression of ion channels in mesenchymal stem cells derived from umbilical cord vein. Stem Cells 25:2044-2052.
Park WS, Heo SC, Jeon ES, Hong da H, Son YK, Ko JH, Kim HK, Lee SY, Kim JH, Han J (2013) Functional expression of smooth muscle-specific ion channels in TGF- $\beta$ (1)-treated human adipose-derived mesenchymal stem cells. Am J Physiol Cell Physiol 305:C377C391.

Tarasov MV, Bystrova MF, Kotova PD, Rogachevskaja OA, Sysoeva VY, Kolesnikov SS (2017) Calcium-gated $\mathrm{K}+$ channels of the $\mathrm{K}_{\mathrm{Ca}} 1.1$ - and $\mathrm{K}_{\mathrm{Ca}} 3.1$-type couple intracellular $\mathrm{Ca}^{2+}$ signals to membrane hyperpolarization in mesenchymal stromal cells from the human adipose tissue. Pflugers Arch-Eur J Physiol 469:349-362.

Tsang WP, Shu Y, Kwok PL, Zhang F, Lee KK, Tang MK, Li G, Chan KM, Chan WY, Wan C (2013) CD146 Human umbilical cord perivascular cells maintain stemness under hypoxia and as a cell source for skeletal regeneration. PLoS One 8: e76153.

Wang K, Xue T, Tsang SY, Van Huizen R, Wong CW, Lai KW, Ye Z, Cheng L, Au KW, Zhang J, Li GR, Lau CP, Tse HF, Li RA (2005) Electrophysiological properties of pluripotent human and mouse embryonic stem cells. Stem Cells 23:1526-1534.

Qiu AW, Bian Z, Mao PA, Liu QH (2016) IL-17A exacerbates diabetic retinopathy by impairing Müller cell function via Act1 signaling. Exp Mol Med 48:e280. 